\title{
A new Aculodes species (Prostigmata: Eriophyoidea: Eriophyidae) associated with medusahead, Taeniatherum caput-medusae (L.) Nevski (Poaceae)
}

\author{
ENRICO DE LILLO ${ }^{1}$, BILJANA VIDOVIĆ ${ }^{2}$, RADMILA PETANOVIĆ ${ }^{2}$, MASSIMO \\ CRISTOFARO ${ }^{3,4}$, FRANCESCA MARINI ${ }^{4}$, MATTHEW AUGÉ ${ }^{4}$, TATJANA CVRKOVIĆ ${ }^{5}$, \\ EMILIJA BABIĆ ${ }^{2}$, CHIARA MATTIA ${ }^{6}$, PARISA LOTFOLLAHI ${ }^{7} \&$ BRIAN G. RECTOR $^{8^{*}}$ \\ ${ }^{1}$ Dipartimento di Scienze del Suolo, della Pianta e degli Alimenti (DiSSPA), University of Bari Aldo Moro, via Amendola, \\ 165/a, I-70126 Bari, Italy, enrico.delillo@uniba.it \\ ${ }^{2}$ University of Belgrade, Faculty of Agriculture, Department of Entomology and Agricultural Zoology, Nemanjina 6, 11080 \\ Belgrade-Zemun, Serbia \\ ${ }^{3}$ Centro di Ricerca Casaccia, Agenzia Nazionale Nuove Tecnologie, Energia, e Sviluppo Economico (ENEA), Via Anguilla- \\ rese,301, I-00123 Rome, Italy, massimo.cristofaro.cas@enea.it \\ ${ }^{4}$ Biotechnological and Biological Control Agency (BBCA) onlus, Via Angelo Signorelli, 105, I-00123 Rome, Italy, \\ m.cristofaro55@gmail.com,fra.rini@gmail.com,matthew.auge@gmail.com \\ ${ }^{5}$ Institute for Plant Protection and Environment, Banatska 33, 11080 Belgrade, Serbia, tanjacvrkovic@yahoo.com \\ ${ }^{6}$ Parco Nazionale dell'Alta Murgia, Via Firenze, 10, I-70024 Gravina in Puglia, Bari, Italy, chiaramattia@ parcoaltamur- \\ gia.it \\ ${ }^{7}$ Department of Plant Protection, Faculty of Agriculture, Azarbaijan Shahid Madani University, Tabriz, Iran, Prslotfol- \\ lahy@yahoo.com \\ ${ }^{8}$ USDA-ARS, Great Basin Rangelands Research Unit, 920 Valley Road, Reno, NV, 89512 USA, Brian.Rector@ars.usda.gov \\ * Corresponding author. E-mail: Brian.Rector@ARS.USDA.GOV
}

\begin{abstract}
A new species of plant mite (Acari: Eriophyidae) was discovered on medusahead (Taeniatherum caputmedusae), an annual grass that is native to central Asia and the Mediterranean Basin. It is invasive in western North America. Aculodes altamurgiensis sp. nov., is described here and differentiated from other Aculodes spp., on the basis of morphology. Its DNA fingerprinting was reported and compared with Aculodes mckenziei collected from Elymus repens and Bromus inermis. Pairwise comparison of MT-CO1 sequences between A. altamurgiensis sp. nov., and A. mckenziei revealed 20.2-21.5\% genetic divergence between these congeneric species. First collected in Parco Nazionale dell' Alta Murgia in Apulia, Italy in 2014, A. altamurgiensis sp. nov., has been subsequently collected from medusahead in Serbia, Bulgaria, Iran and Turkey. Based on these data and on preliminary observations on the effects of the mite on plant growth, A. altamurgiensis sp. nov., is currently being investigated as a candidate biological control agent of medusahead.
\end{abstract}

Key words: Apulia, biological control, conservation, grasses, weeds

\section{Introduction}

All mites in the family Eriophyidae are obligate herbivores. Many of them are crop pests, some of which can transmit viruses (Petanović \& Kielkiewicz 2010); while others are associated with weeds and have high potential as classical biological control agents (Rosenthal 1996; Smith et al. 2010). Several eriophyid species have been released as biological control agents but to date, none have been released to control grass targets (Smith et al. 2010; Winston et al. 2014). 
Species in the genus Aculodes Keifer associated with grass hosts are found in many geographic regions; most of them have been reported from the northern hemisphere (de Lillo \& Amrine, unpublished database). To date, about 30 species have been described in the genus Aculodes, of which most were recorded from grasses (Poaceae). The others were found on hosts in the families Malvaceae, Salicaceae, Leguminosae and Rosaceae (Alemandri et al. 2015, Boczek \& Chandrapatya 1998; Huang 1992, 2001; Keifer 1944, 1952, 1960, 1966a, 1966b; Kuang 1997; Kuang \& Pang 1997; Kuang et al. 2005; Nalepa 1891; Shi \& Boczek 2000; Skoracka 2003, 2004, 2005; Skoracka \& Pacyna 2005; Skoracka et al. 2001, 2009; Sukhareva 1972, 1981, 1985, 1986, 1994; Xue et al. 2010, 2012).

Medusahead, Taeniatherum caput-medusae (L.) Nevski (Poaceae), is a winter annual grass native to western Asia and the Mediterranean Basin (Frederiksen 1986). It has become invasive in western North America, spreading rapidly and degrading rangeland habitats (Young \& Evans 1970; Davies \& Johnson 2008). It is currently the target of a classical biological control program, with a focus on the discovery and development of eriophyid mite natural enemies as biological control agents (Rector B.G., pers. comm.). In the course of native range surveys for eriophyid mites on medusahead, an unidentified Aculodes sp., was collected in the Parco Nazionale dell'Alta Murgia in Apulia, Italy, as well as in Serbia, central Turkey, northern Iran and Bulgaria. This report presents the description of this new eriophyoid mite species, Aculodes altamurgiensis sp. nov.

\section{Material and methods}

Collection and Light Microscopy Morphological Study

Plant samples of T. caput-medusae were collected from Italy, Serbia, Bulgaria, Turkey, and Iran from 2014 to 2017 and examined in the laboratory. Mites were removed from the plants using a fine needle under a dissection stereomicroscope and by using extraction methods described by de Lillo (2001) and Monfreda et al. (2007). Mites were mounted in Keifer's F medium (Amrine \& Manson 1996) and then examined using two phase-contrast microscopes (Leica DMLS, Wetzlar, Germany; Olympus BX50, Hamburg, Germany). Morphology and nomenclature follow Lindquist (1996) and genus classification is based on Amrine et al. (2003). Measurements and illustrations were made according to Amrine and Manson (1996) and de Lillo et al. (2010). Morphometry was performed using the software package IM 1000 (Leica, Wetzlar, Germany) and for hand-drawn line art a camera lucida was used. All measurements are given in micrometers $(\mu \mathrm{m})$ and, unless stated otherwise, are the length of the structure. Plant names are in accordance with The Plant List (2013) on-line database.

The holotype and the paratype slides are deposited in the collections of the Acarology Laboratory, Department of Entomology and Agricultural Zoology, Faculty of Agriculture, University of Belgrade, Serbia; one paratype slide is deposited at the Dipartimento di Scienze del Suolo, della Pianta e degli Alimenti (DiSSPA), University of Bari Aldo Moro, Italy.

\section{Scanning Electron Microscopy Study}

Scanning electron micrographs (SEM) were taken according to Nuzzaci and Vovlas (1976) (see also Alberti \& Nuzzaci 1996). Live mites were collected individually using a fine pin from fresh plant material under a stereomicroscope. For specimen preparation before being placed on the SEM stage, mites were sputter-coated with gold for $100 \mathrm{~s}$ under $30 \mathrm{~mA}$ ion current. The mites were then studied in the vacuum chamber of a JEOL Scanning Electron Microscope (JEOL-JSM6390, Peabody, MA, USA) at the Laboratory of Electron Microscopy, Faculty of Agriculture, University of Belgrade, Serbia. 


\section{DNA Extraction, PCR Amplification and Sequencing}

Material collected for molecular analysis included populations from Italy and Serbia (Table 1). Mites for DNA extraction were collected from fresh plant material, preserved in $96 \%$ ethanol and stored at $-20^{\circ} \mathrm{C}$. Total genomic DNA was extracted from a pool of 20 whole mites using a QIAGEN DNeasy ${ }^{\circledR}$ Blood \& Tissue Kit (QIAGEN, Hilden, Germany), according to the manufacturer's instructions. DNA samples are archived at $-80{ }^{\circ} \mathrm{C}$ at the Institute for Plant Protection and Environment (Belgrade, Serbia).

Amplification of a $658 \mathrm{bp}$ barcode fragment of subunit I of the mitochondrial cytochrome $\mathrm{c}$ oxidase gene (MT-CO1) was performed in $25 \mu \mathrm{l}$, using primers LCO1490 and HCO2198 (Folmer et al. 1994), following reaction conditions specified by Chetverikov et al. (2012). PCR products were separated by electrophoresis through a 1\% agarose gel in TBE buffer (Tris-Borate $90 \mathrm{mM}$, EDTA 1 $\mathrm{mM}$ ), then stained with ethidium bromide for visualization under a UV transilluminator.

Amplicons were purified using the QIAquick PCR purification Kit (QIAGEN) according to the manufacturer's instructions and then sequenced on automated equipment by Macrogen (Seoul, South Korea) with the $\mathrm{HCO} 2198$ primer (the reverse primer in the initial PCR procedure). The sequences were manually edited using FinchTV v. 1.4.0 (www.geospiza.com), and aligned by CLUSTAL W (integrated within MEGA5 software; Tamura et al. 2011). Uncorrected pairwise genetic distances were used to calculate the average genetic distance between A. altamurgiensis $\mathbf{s p .}$ nov., populations associated with T. caput-medusae collected from Italy and Serbia (Table 1).

TABLE 1. Collection data for Aculodes altamurgiensis sp. nov., inhabiting Taeniatherum caputmedusae populations.

\begin{tabular}{lllll}
\hline & Country & Locality,-date & GPS coordinates & Name of collector \\
\hline 1 & Italy & Castel del Monte, May 2015 & $41^{\circ} 03^{\prime} 58.2^{\prime \prime} \mathrm{N}, 16^{\circ} 15^{\prime} 21.6^{\prime \prime} \mathrm{E}$ & Cristofaro M. \\
2 & Serbia & Krševica, May 2016 & $42^{\circ} 25^{\prime} 51^{\prime \prime N}, 21^{\circ} 52^{\prime} 5^{\prime \prime} \mathrm{E}$ & Rector B. \\
3 & Serbia & Aleksandrovačko jezero, May 2016 & $42^{\circ} 29^{\prime} 11^{\prime \prime N}, 21^{\circ} 53^{\prime} 48^{\prime \prime} \mathrm{E}$ & Rector B.
\end{tabular}

Sequences of $A$. altamurgiensis sp. nov., were trimmed and compared with the two corresponding sequences of Aculodes mckenziei (Keifer), collected from Elymus repens and Bromus inermis, which are available in the NCBI database (GenBank accession numbers FJ387561 and FJ387562). Currently, these A. mckenziei sequences are the only COI sequences of any Aculodes spp., that have been recorded in GenBank.

\section{Results}

\section{Aculodes altamurgiensis sp. nov., de Lillo \& Vidović}

Description. FEMALE ( $\mathrm{n}=10)$. Body wormlike 225 (212-286), 53 (53-67) wide, whitish in color. Gnathosoma 19 (19-20) curved downwards, chelicerae 14 (14-16), setae ep 3, setae $d 7$ (7-9) unbranched. Prodorsal shield 36 (32-42) including the frontal lobe, 29 (28-33) wide, triangular with a pronounced, elongated and pointed frontal lobe over the gnathosoma; median line present in the posterior half of the shield; admedian lines complete, subparallel; I pair of submedian lines present, paired, incomplete, subparallel to admedian, in the central part of the shield; II pair of submedian lines present, paired, incomplete, parallel to lateral shield margins; dashes present on rear surface of the shield and between the lines. Tubercles $s c$ subcylindrical, on rear shield margin 24 
(22-25) apart, scapular setae sc 39 (39-53). Leg I 34 (33-36); femur 9 (8-10), setae $b v 18$ (13-19); genu 6 (6-7), setae $l^{\prime \prime} 25$ (24-29); tibia 8 (7-8), setae $l^{\prime} 12$ (10-12); tarsus 7 (7-9), setae $f t^{\prime} 18$ (18$26)$, setae $f t^{\prime \prime} 7$ (7-14); tarsal solenidion $\omega 10$ (8-10) with a thinner and rounded end; tarsal empodium 8 (6-9), 7-rayed. Leg II 33 (31-34); femur 9 (9-10), setae bv 17 (14-21); genu 6 (5-6), setae $l^{\prime \prime} 17$ (16-25); tibia 7 (6-7); tarsus 8 (7-8), setae $f t^{\prime} 26$ (20-28), setae $f t^{\prime \prime} 10$ (9-12); tarsal solenidion $\omega 9$ (8-11) similar to that on leg I; tarsal empodium 10 (7-10), 7-rayed. Coxae sparsely granulated and with short lines; sternal line 9 (9-11); setae $1 b 9$ (9-11), tubercles $1 b 9$ (9-13) apart; setae $1 a 15$ (13-24), tubercles $1 a 8$ (8-13) apart, setae $2 a 28$ (23-44), tubercles $2 a 23$ (19-27) apart. Genital coverflap 11 (11-15), 21 (18-22) wide, with 10 (10-11) longitudinal striae in a single row; setae $3 a 20$ (18-23), 16 (14-20) apart. Internal genitalia with anterior apodeme trapezoidal, longitudinal bridge relatively long, the post spermathecal part of the longitudinal bridge is reduced; spermathecal tubes directed latero-posterad, composed of two parts: basal part egg-shaped, distal part more tubulose; spermathecae globose. Opisthosoma with subequal annuli: 53 (51-58) dorsal and 56 (55-66) ventral annuli; 5 (5-6) coxigenital annuli. Dorsal and ventral opisthosoma with pointed microtubercles close to the rear margins of annuli. Setae $c 235$ (30-43), 48 (48-53) apart, on annulus 8 (7-9); setae $d 30$ (28-41), 26 (26-40) apart, on annulus 12 (12-15); setae $e$ 18 (17-31), 14 (14-20) apart, on annulus 26 (26-32); setae $f 22$ (22-29), 20 (20-24) apart, on annulus 49 (47-54); seta $h 251$ (51-80), 10 (10-11) apart; setae $h 110$ (7-10), 6 (6-7) apart.

MALE (n=2). Body wormlike, 211, 44 wide, whitish in color. Gnathosoma 18-20 curved down, cheliceral stylets 12. Prodorsal shield 31-34, 36 wide. Prodorsal shield tubercles on the rear shield margin 18-19 apart, setae sc 32-34, projecting posteriorly. Shield design similar to female. Leg I 26-28; femur 7, setae $b v$ 11-12; genu 4-5, setae $l^{\prime \prime} 21$, tibia 5, tibial setae $l$ ' 5; tarsus 6, setae $f t^{\prime} 12$, setae $f t^{\prime \prime} 14-15$; solenidion $\omega$ 6-8, empodium em 5-6, and 7-rayed. Leg II 23-26; femur 7, setae $b v$ 15; genu 4, genual setae $l^{\prime \prime} 12$, tibia 5; tarsus 6; setae $f t^{\prime} 6$, setae $f t^{\prime \prime} 14-16$; solenidion $\omega 8$ 9, empodium em 6. Coxae granulated; sternal line 6-7; setae $1 b$ 6-7, 1 b tubercles 8 apart; setae $1 a$ 18, 1a tubercles 5 apart; setae $2 a$ 26-28, 2a tubercles 18-19 apart. Genitalia 19-20 wide; setae $3 a$ 11-16, $3 a$ tubercles 11-15 apart. Opisthosoma with subequal annuli: 57-63 dorsal and 61-63 ventral annuli; 6 coxigenital annuli. Setae $c 2$ 24-27, 44 apart, on annulus 9-11; setae $d$ 36-37, 2829 apart, on annulus 19-21; setae $e$ 16-17, 11-13 apart, on annulus 34-35; setae $f 14$, 18 apart, on annulus 57-59; setae $h 2$ 55-72, 7 apart, setae $h 1$ 4-5, 4 apart.

Type host plant. Taeniatherum caput-medusae (L.) Nevski (Poaceae), medusahead.

Type locality. Road SP $234 \mathrm{Km} \mathrm{19}$, about $2 \mathrm{~km}$ west of Castel del Monte (Andria) $\left(41.0662^{\circ} \mathrm{N}\right.$, $\left.16.256^{\circ} \mathrm{E}\right), 504 \mathrm{~m}$ above sea level, Apulia, Italy

Type material. Female holotype (slide \#654/3) and paratypes: 12 females, 4 males; 13 May 2015, by M. Cristofaro, A. Paolini and D. De Simone.

Additional studied materials. Castel del Monte, Apulia, Italy $\left(41.0662^{\circ} \mathrm{N}, 16.256^{\circ} \mathrm{E}\right), 27$ May 2014, 10 slides; 3 May 2016, 2 slides 8 December 2016, 11 slides; 8 February 2017, 1 slide. Davidovac (Kladovo), Serbia $\left(44.6350^{\circ} \mathrm{N}, 22.5477^{\circ} \mathrm{E}\right), 1$ June 2015; 15 slides; 30 May 2016, 2 slides. Krševica (Vranje), Serbia (42.4312 $\left.{ }^{\circ} \mathrm{N}, 21.868{ }^{\circ} \mathrm{E}\right), 3$ June 2015, 12 slides; 25 April 2016, 4 slides; 29 May 2016, 2 slides. Aleksandrovačko jezero (Vranje), Serbia (42.4865 $\left.{ }^{\circ} \mathrm{N}, 21.8965^{\circ} \mathrm{E}\right)$, 29 May 2016, 20 slides. Chernoochene, Bulgaria $\left(41.7768{ }^{\circ} \mathrm{N}, 25.342{ }^{\circ} \mathrm{E}\right), 5$ June 2015, 9 slides; Varovnik (Sredetz), Bulgaria (42.2191 $\left.{ }^{\circ} \mathrm{N}, 27.154{ }^{\circ} \mathrm{E}\right), 6$ June 2015, 5 slides; Barzitsa (Provadia), Bulgaria $\left(43.0729^{\circ} \mathrm{N}, 27.526^{\circ} \mathrm{E}\right), 7$ June 2015, 5 slides; Cavusin, Turkey $\left(38.7406^{\circ} \mathrm{N}, 35.027{ }^{\circ} \mathrm{E}\right)$, 16 April 2015, 6 slides; Soufian (East Azerbaijan), Iran (38.3178 $\left.{ }^{\circ} \mathrm{N}, 45.943{ }^{\circ} \mathrm{E}\right)$, June 2017, 15 slides. Specimens collected by M. Cristofaro, F. Di Cristina, E. de Lillo, P. Lotfollahi, F. Marini, M. Augé, S. Marinković, A. Paolini, R. Petanović, B. Rector, D. Smiljanić, and B. Vidović. 


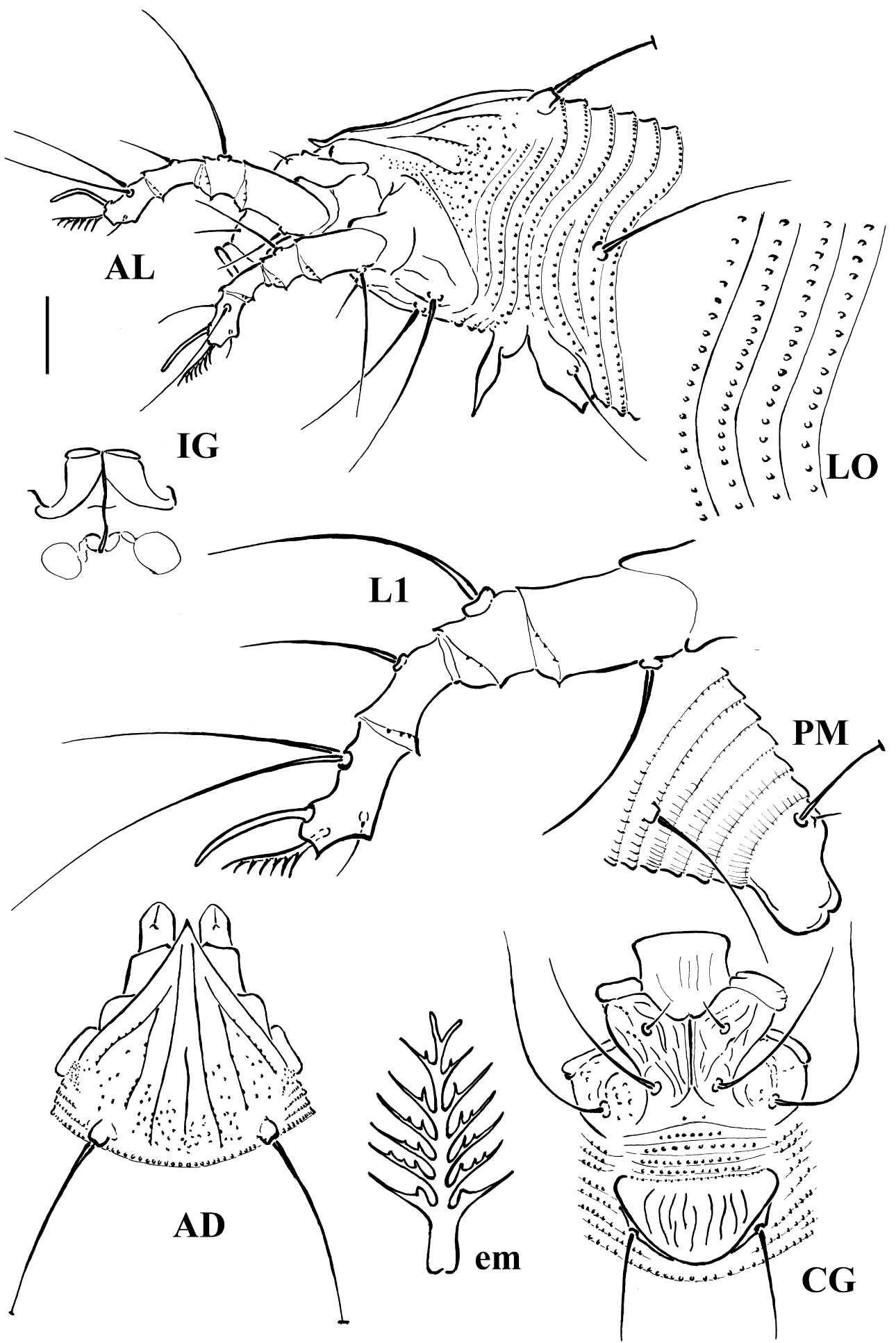

FIGURE 1. Line drawings of Aculodes altamurgiensis sp. nov.: AD. Prodorsal shield; AL. Lateral view of anterior body region; CG. Female coxigenital region; em. Empodium; IG. Internal female genitalia; LO. Lateral view of annuli; L1. Leg I; PM. Lateral view of posterior opisthosoma. Scale bar: $10 \mu \mathrm{m}$ for AD, AL, CG, GM, IG, PM; $5 \mu \mathrm{m}$ for LO, L1; $2.5 \mu \mathrm{m}$ for em. 

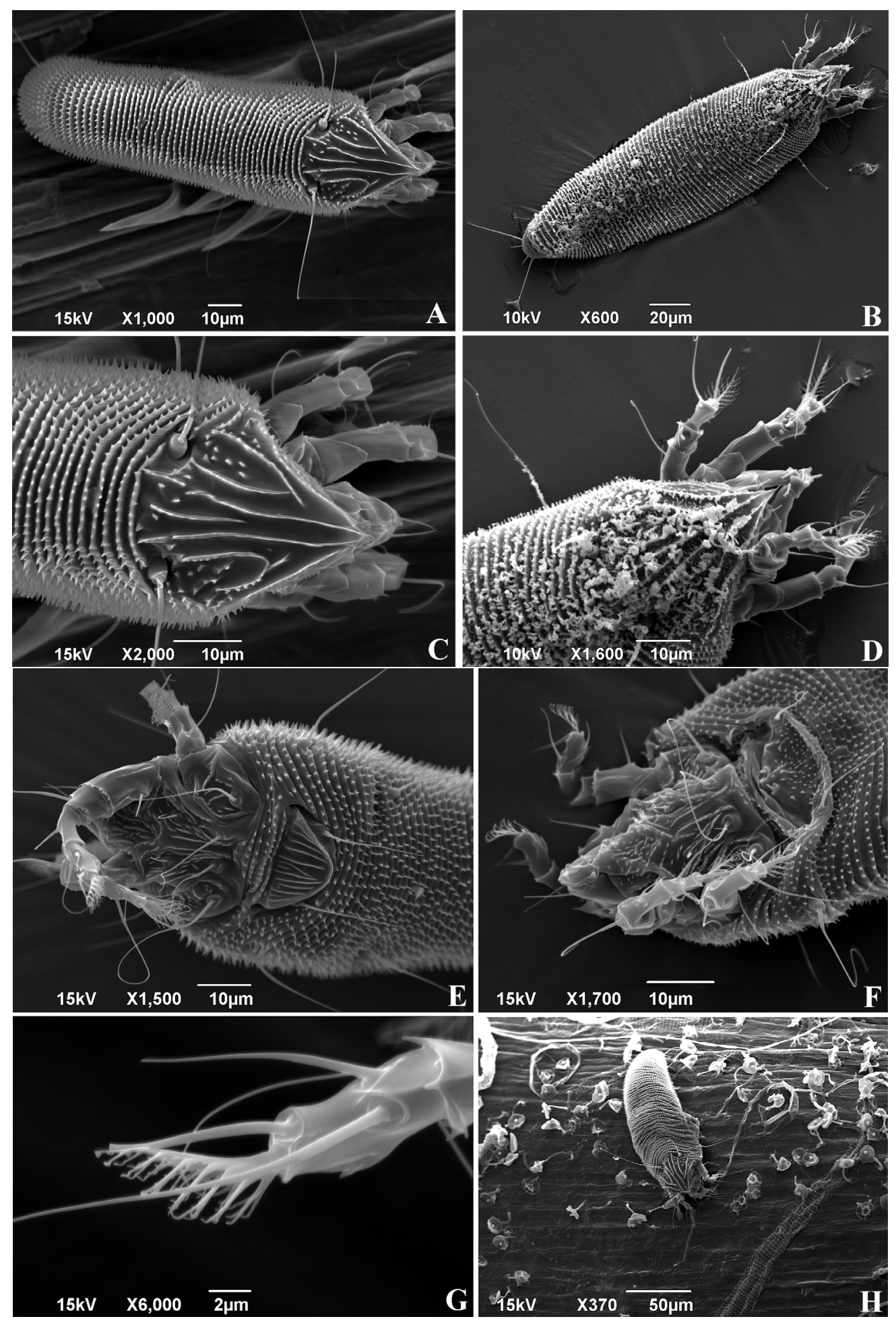

FIGURE 2. Scanning electron micrographs of Aculodes altamurgiensis sp. nov.: A. Dorsal view; B. Dorsal view with apparent wax-like secretion; $C$. Dorsal view with the detail of pro-dorsal shield; D. Dorsal view with detail of tarsi and apparent wax-like secretion; E. Ventral view, anterior half; F. Ventral view, anterior half; G. Detail of tarsus; H. Portion of medusahead leaf with adult and spermatophores. 
Relation to the host. Mites were observed as vagrants more easily on mature medusahead plants in late spring, apparently preferring sheltered parts of the plant (e.g. on the stem protected by leaves, on ripening seeds within inflorescences). Preliminary observations indicated an impact on seed germination rate, although additional studies under controlled conditions will be necessary.

Etymology. The specific epithet altamurgiensis is an adjective, derived from the name of the Parco Nazionale dell'Alta Murgia, where the mite was first collected, in the plural genitive case.

Differential diagnosis and remarks. Based on the presence and length of the median line on the prodorsal shield, A. altamurgiensis sp. nov. (median line present in the posterior half of the shield) can be distinguished from species without a median line (A. capillarisi Skoracka, A. dubius (Nalepa), A. janboczeki Skoracka, A. koeleriae Sukhareva, A. kransnovi Sukhareva, A. stoloniferae Skoracka, A. sylvatici Skoracka, Labrzycka \& Rector) and species with complete median line ( $A$. bambusae Kuang, A. levis Huang, A. ponticus Sukhareva).

Aculodes altamurgiensis sp. nov., can be distinguished from other Aculodes spp., with incomplete median lines and the same number of empodial rays based on the shape, presence, and position of their submedian lines. Aculodes altamurgiensis sp. nov., has two submedian, incomplete,straight lines in the central part of the shield (one in the field between the tubercles $s c$ and the admedian line; one in the field between the tubercle $s c$ and the lateral side of the prodorsal shield) that touch each other at their anterior ends. Aculodes calamaabditus Skoracka and $A$. deschampsiae (Sukhareva) each have one pair of submedian lines; A. tsukushiensis Xue, Song \& Hong has a complete pair of inner submedian lines which do not cross the outer pair of submedian lines; A. festucae Skoracka, Labrzycka \& Rector and A. mckenziei (Keifer) have a pair of curved and complete outer submedian lines; A. neglectivagrans Skoracka has two short pairs of submedian lines that do not touch; A. fulleri (Keifer) has an inner pair of submedian lines is on the anterior half.

Aculodes altamurgiensis sp. nov., can be distinguished from $A$. mongolicus by the length of the prodorsal shield (32-42 $\mu \mathrm{m}$ in A. altamurgiensis sp. nov. $42-46 \mu \mathrm{m}$ in A. mongolicus), the width of shield (28-33 $\mu \mathrm{m}$ in A. altamurgiensis sp. nov. $42-44 \mu \mathrm{m}$ in A. mongolicus), the length of 1 a setae (13-24 $\mu \mathrm{m}$ in A. altamurgiensis sp. nov. 24-33 $\mu \mathrm{m}$ in A. mongolicus), the length of $3 a$ setae (18-23 $\mu \mathrm{m}$ in A. altamurgiensis, sp. nov. 38-48 $\mu \mathrm{m}$ in A. mongolicus), the length of $c 2$ setae $(30-43 \mu \mathrm{m}$ in A. altamurgiensis sp. nov. $40-47 \mu \mathrm{m}$ in A. mongolicus), the length of $d$ setae $(28-41 \mu \mathrm{m}$ in $A$. altamurgiensis sp. nov. 59-61 $\mu \mathrm{m}$ in A. mongolicus) and length of $e$ setae $(17-31 \mu \mathrm{m}$ in $A$. altamurgiensis sp. nov. 30-38 $\mu \mathrm{m}$ in A. mongolicus).

According to the prodorsal shield design A. altamurgiensis sp. nov., is most similar to Aculodes holcusi, but there are numerous characters that differ between these two species, including number of empodial rays (A. altamurgiensis sp. nov. 7-rayed; A. holcusi, 8-rayed); length of $s c, 1 a, 2 a, c 2$, $d, e$ and $f$ setae (A. altamurgiensis sp. nov., has shorter setae in each case compared to A. holcusi); width of prodorsal shield (28-33 $\mu \mathrm{m}$ in A. altamurgiensis sp. nov. 49-51 $\mu \mathrm{m}$ in A. holcusi); length

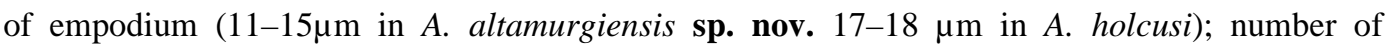
longitudinal striae on the coverflap (10 in A. altamurgiensis sp. nov. 12 in A. holcusi).

Biological and ecological remarks. Surveys and field samples on native and cultivated grasses were carried out at the site near Castel del Monte, Parco Nazionale dell'Alta Murgia, where the mite was recorded for the first time on medusahead. Starting on 7 May 2015, and repeating observations after 2 weeks, twenty samples of several Poaceae (the target weed, 2 species of cultivated wheat, Triticum durum Desf. and T. aestivum L., and the wild species Stipa capensis Thunb., Avena sativa L. and Hordeum murinum L.) were randomly collected and inspected for the mite presence. In some of these species (A. sativa, S. capensis), as well on T. caput-medusae, eriophyid mites were recorded, but morphological identification showed that A. altamurgiensis sp. nov., was recorded only on the target weed species (unpublished data). Adults and juveniles were collected from seedling medusahead plants in winter, indicating that females were present and reproducing. Seedling 
medusahead plants infested with A. altamurgiensis that were collected from the field in late summer 2016 and transplanted to pots outside the laboratory (i.e. under ambient climatic conditions) grew normally and supported relatively dense populations of the mite through the summer of 2017. Closer observations under controlled conditions are required to quantify the physiological impact of $A$. altamurgiensis sp. nov., on medusahead. Additional host-range resting is also required in order to assess the suitability of $A$. altamurgiensis sp. nov., as a biological control agent for medusahead in the western USA.

\section{Molecular analysis}

The sequencing reaction produced a $606 \mathrm{bp}$ fragment of the MT-CO1 barcode region. Base pair frequencies showed that the region is AT-rich $(61.3 \%$ and $61.9 \%$ for the Italian and Serbian populations, respectively). The translation of the nucleotide sequences resulted in a 202 amino acid positions.

Two different haplotypes were obtained for populations of $A$. altamurgiensis sp. nov., collected in Italy and Serbia, with no insertions or deletions occurring between the respective MT-CO1 sequences. Sequence comparison revealed minor genetic variability represented with 8 singleton polymorphisms, resulting in no amino-acid replacement. Genetic divergence over the sequence pairs was $1.3 \%$ (Table 2). The sequences are available from GenBank under accession numbers \#MH352403, \#MH352404, and \#MH352405.

TABLE 2. Uncorrected p-distance among Aculodes altamurgiensis sp. nov., populations collected from Taeniatherum caput-medusae at different localities.

\begin{tabular}{llllll}
\hline & Population-Locality & 1 & 2 & 3 & GenBank accession no. \\
\hline 1 & Italy-Castel del Monte & & & \#MH352403 \\
2 & Serbia-Krsevica & 0.013 & & \#MH352404 \\
3 & Serbia-Aleksandrovacko jezero & 0.013 & 0.00 & \#MH352405 \\
\hline
\end{tabular}

Pairwise comparison of overlapping MT-CO1 fragments (531 nt) between A. altamurgiensis $\mathbf{s p . ~}$ nov., from Italy and A. mckenziei collected from Elymus repens and Bromus inermis resulted in $20.2 \%$ and $21.5 \%$ genetic divergence, respectively. Populations of A. altamurgiensis sp. nov., from Serbia showed $20.2 \%$ and $21.3 \%$ sequence divergence between the congeneric species from Elymus repens and Bromus inermis, respectively. Translation into amino acid sequences revealed $4.5 \%$ divergence between populations of A. altamurgiensis sp. nov., from both Italy and Serbia, and $A$. mckenziei inhabiting both Elymus repens and Bromus inermis.

The morphometric results presented in this study suggest that A. altamurgiensis sp. nov., is a distinct species. This data, combined with the observed variation between $\mathrm{CO} 1$ sequences of $A$. altamurgiensis and the two A. mckenziei samples from different hosts provide additional, persuasive evidence of this assertion.

\section{Acknowledgements}

This study was supported by the Serbian Ministry of Education and Science (Grant\# III43001) and in part by the Italian Ministry of Education (Progetto Pietro Della Valle). Special thanks to Dragica Smiljanić (University of Belgrade), to Vili Harizanova and Atanaska Stoeva (Agrarian University, Plovdiv, Bulgaria) to Francesca Di Cristina, Silvietta Barlattani, Daniele De Simone and Alessandra Paolini (BBCA) and to the master students Gerardo Roselli and Fabrizio Freda (University of Rome La Sapienza), for their essential support in the first surveys, collections and samplings of the mite. 


\section{References}

Alberti, G. \& Nuzzaci, G. (1996) SEM and TEM Techniques. In: Lindquist, E.E., Sabelis, M.W. \& Bruin, J. (eds.) Eriophyoid Mites. Their Biology, Natural Enemies and Control. World Crop Pest Vol. 6. Amsterdam, Elsevier Science Publishers. pp. $399-410$

Alemandri, V., Truol, G., De Mendonça, R.S. \& Navia, D. (2015) Eriophyid mites in the genus Aculodes Keifer (Prostigmata: Eriophyidae) from grasses - the first taxon from South America and world species information. International Journal of Acarology, 41, 429-441. http://dx.doi.org/10.1080/01647954.2015.1050063

Amrine, J.W. Jr. \& Manson, D.C.M. (1996) Preparation, mounting and descriptive study of Eriophyoid mites. In: Lindquist, E.E., Sabelis, M.W. \& Bruin, J. (eds.) Eriophyoid Mites. Their Biology, Natural Enemies and Control. World Crop Pest Vol. 6. Amsterdam, Elsevier Science Publishers, pp. 383-396.

Amrine, J.W. Jr., Stasny, T.A. \& Flechtmann, C.H.W. (2003) Revised keys to world genera of Eriophyoidea (Acari: Prostigmata). West Bloomfield, Michigan, USA, Indira Publishing House, 244 pp.

Boczek, J. \& Chandrapatya, A. (1998) Studies on eriophyoid mites (Acari: Eriophyoidea). XXII. Acarologia, 39, 134-142.

Chetverikov, P.E., Beaulieu, F., Cvrković, T., Vidović, B. \& Petanović, R. (2012) Oziella sibirica (Acari: Eriophyoidea: Phytoptidae), a new eriophyoid mite species described using confocal microscopy, COI barcoding and 3D surface reconstruction. Zootaxa, 3560, 41-60.

Davies, K.W. \& Johnson, D.D. (2008) Managing medusahead in the Intermountain West is at a critical threshold. Rangelands, 30, 13-15. http://dx.doi.org/10.2111/1551-501X(2008)30[13:MMITIW]2.0.CO;2

de Lillo, E. (2001) A modified method for eriophyoid mite extraction (Acari, Eriophyoidea). International Journal of Acarology, 27, 67-70. http://dx.doi.org/10.1080/01647950108684228

de Lillo, E., Craemer, C., Amrine, J.W.Jr. \& Nuzzaci, G. (2010) Recommended procedures and techniques for morphological studies of Eriophyoidea (Acari: Prostigmata). Experimental and Applied Acarology, 51, $283-307$. http://dx.doi.org/10.1007/s10493-009-9311-x

Folmer, O., Black, M., Hoeh, W., Lutz, R. \& Vrijenhoek, R. (1994) DNA primers for amplification of mitochondrial cytochrome c oxidase subunit I from diverse metazoan invertebrates. Molecular Marine Biology \& Biotechnology, 3, 294299.

Frederiksen, S. (1986) Revision of Taeniatherum (Poaceae). Nordic Journal of Botany, 6, 389-397. http://dx.doi.org/10.1111/j.1756-1051.1986.tb00894.x

Huang, K.-W. (1992) Some new eriophyoid mites from Taiwan (Acarina: Eriophyoidea). Bulletin of the National Museum of Natural Sciences, 3, 225-240.

Huang, K.-W. (2001) Eriophyid mites of Taiwan: description of eighty-six species from the Tengchih Area. Bulletin of the National Museum of Natural Sciences, 14, 1-84.

Keifer, H.H. (1944) Eriophyid Studies XIV. Bulletin of the California Department of Agriculture, 33, 18-38.

Keifer, H.H. (1952) The eriophyid mites of California. Bulletin of the California Insect Survey 2, 1-123.

Keifer, H.H. (1960) Eriophyid Studies B-1. Sacramento, California, USA, Bureau of Entomology, California Department of Agriculture, $20 \mathrm{pp}$.

Keifer, H.H. (1966a) Eriophyid Studies B-20. Sacramento, California, USA, Bureau of Entomology, California Department of Agriculture, $20 \mathrm{pp}$.

Keifer, H.H. (1966b) Eriophyid Studies B-21. Sacramento, California, USA, Bureau of Entomology, California Department of Agriculture, $20 \mathrm{pp}$

Kuang, H.-Y. (1997) Four new species of Eriophyidae (Acari: Eriophyoidea) from China. Entomotaxonomia, 19, 74-78.

Kuang, H.-Y. \& Pang, H.-L. (1997) Four new species of the Eriophyinae (Acari: Eriophyidae) from China. Entomotaxonomia, 19, 230-234.

Kuang, H.-Y., Luo, G.-H. \& Wang, A.-W. (2005) Fauna of Eriophyid Mites from China (II) (Acari: Eriophyoidea). Beijing, China Forestry Publishing House, 176 pp.

Lindquist, E.E. (1996) External anatomy and notation of structures. In: Lindquist, E.E., Sabelis, M.W. \& Bruin, J. (eds.) Eriophyoid Mites. Their Biology, Natural Enemies and Control. World Crop Pest Vol. 6. Amsterdam, Elsevier Science Publishers, pp. 3-31. http://dx.doi.org/10.1016/S1572-4379(96)80003-0

Mason-Gamer, R.J. (2005) The B-amylase genes of grasses and a phylogenetic analysis of the Triticeae (Poaceae). Anerican Journal of Botany, 92, 1045-1058. https://doi.org/10.3732/ajb.92.6.1045 
Monfreda, R., Nuzzaci, G. \& de Lillo, E. (2007) Detection, extraction, and collection of Eriophyoid mites. Zootaxa, 1662, $35-43$.

Nalepa, A. (1891) Genera und Species der Fam. Phytoptida. Anzeiger der kaiserlichen Akademie Wissenschaften. Mathematische-naturwissenschaftliche Klasse, Wien, 28, 162.

Nuzzaci, G. \& Vovlas, N. (1976) Osservazione dei caratteri tassinomici degli Eriofidi al microscopio elettronico a scansione. In: Atti XI Congresso Nazionale Italiano di Entomologia, Portici-Sorrento, 10-15 maggio 1976, pp. 117-122.

Petanović, R. \& Kielkiewicz, M. (2010) Plant-eriophyoid mite interactions: specific and aspecific morphological alterations. Part II. Experimental and Applied Acarology, 51, 81-91. http://dx.doi.org/10.1007/s10493-009-9328-1

Rosenthal, S.S. (1996) Aceria, Epitrimerus and Aculus species and biological control of weeds. In: Lindquist, E.E., Sabelis M.W. \& Bruin, J. (eds.) Eriophyoid Mites. Their Biology, Natural Enemies and Control. World Crop Pest Vol. 6. Amsterdam, Elsevier Science Publishers, pp 729-739

Shi, A.-X. \& Boczek, J. (2000) Studies on eriophyoid mites (Acari: Eriophyoidea). XXXIX. Bulletin of the Polish Academy Sciences, Biological Science, 48, 319-334.

Skoracka, A. (2003) New species of Aculodes (Acari: Eriophyoidea) from grasses in Poland. Acta Zoologica Academiae Scientiarum Hungaricae, 49, 43-60.

Skoracka, A. (2004) Eriophyoid mites from grasses in Poland (Acari: Eriophyoidea). Genus, (suppl.) 13, 1-205.

Skoracka, A. (2005) Two new species and four new records eriophyoid mites from grasses in Hungary (Acari: Eriophyoidea). Genus, 16, 445-462.

Skoracka, A. \& Pacyna, A. (2005) Grass-associated eriophyoid mites (Acari: Eriophyidae) from the Kola Peninsula, Russia. Annales Zoologici, 55, 453-466.

Skoracka, A., Shi, A.-X. \& Pacyna, A. (2001) New eriophyoid mites (Acari: Eriophyoidea) associated with grasses from Mongolia. Zootaxa, 9, 1-18. https://doi.org/10.11646/zootaxa.9.1.1

Skoracka, A., Labrzycka, A. \& Rector, B.G. (2009) Three new species of eriophyoid mites (Acari: Prostigmata: Eriophyoidea) from grass hosts in Croatia. Annals of the Entomological Society of America, 102, 12-19. https://doi.org/10.1603/008.102.0102

Smith, L., de Lillo, E. \& Amrine, J.W. Jr. (2010) Effectiveness of eriophyid mites for biological control of weedy plants and challenges for future research. Experimental and Applied Acarology, 51, 115-149. http://dx.doi.org/10.1007/s10493-009-9299-2

Sukhareva, S.I. (1972) A new species of quadrupedal mites of the genus Phytocoptes (Acarina, Eriopyoidea). Zoologicheskii. Zhurnal, 51, 296-300. (in Russian)

Sukhareva, S.I. (1981) The structure of the four most distributed eriophyid mites (Acarina: Tetrapodili) from grasses: Aceria tritici Shev., Aculodes mckenziei (K.), Aculodes dubius (Nal.), Abacarus hystrix (Nal.). Vestnik Leningradskogo Universiteta 15, 25-36. (in Russian)

Sukhareva, S.I. (1985) New species of mites (Acarina: Eriophyidae, Phyllocoptidae) living on graminaceous plants in the Maritime Territory. Entomologiceskoe Obozrenie, 64, 227-234. Entomological Review, 64, 166-173.

Sukhareva, S.I. (1986) New species of eriophyid mites (Acariformes: Tetrapodili) from grasses. Entomologiceskoe Obozrenie, 65, 850-855. Entomological Review, 66, 186-191.

Sukhareva, S.I. (1994). The four-legged mites (Acariformes: Tetrapodili) on the bamboos in Georgia (Rep.). Vestnik Sankt Petersburgkogo Universiteta, Seriya 3, Biologiya 1,33-38. (in Russian with English summary)

Tamura, K., Peterson, D., Peterson, N., Stecher, G., Nei, M. \& Kumar, S. (2011) MEGA5: Molecular evolutionary genetics analysis using maximum likelihood, evolutionary distance and maximum parsimony methods. Molecular Biology and Evolution, 28, 2731-2739. http://dx.doi.org/10.1093/molbev/msr121

The Plant List (2013) Version 1.1. Published on the Internet. Available from: http://www.theplantlist.org/ (Accessed 27 Feb 2018).

Winston, R.L., Schwarzlaender, M., Hinz, H.L., Day, M.D., Cock, J.W. \& Julien, M.H. (2014) Biological Control of Weeds: a World Catalogue of Agents and their Target Weeds. Fifth Edition, Morgantown, West Virginia, USA, USDA Forest Service, Forest Health Technology Enterprise Team, 838 pp.

Xue, X.-F., Song, Z.-W. \& Hong, X.-Y. (2010) Five new species of Anthocoptini from China (Acari: Eriophyidae). Zootaxa, 2666, 29-44.

Xue, X-F., Sadeghi, H. \& Hong, X.-Y. (2012) Four new eriophyoid mite species (Acari: Eriophyoidea: Eriophyidae) from Iran. Zootaxa, 3544, 28-40.

Young J.A. \& Evans, R.A. (1970) Invasion of medusahead into the Great Basin. Weed Science, 18, 89-97.

Submitted: 28 Feb. 2018; accepted by Zhi-Qiang Zhang: 19 May 2018; published: 28 Jun. 2018 